\title{
Cold agglutinin disease
}

INSERM

\section{Source}

INSERM. (1999). Orphanet: an online rare disease and orphan drug data base. Cold agg/utinin disease. ORPHA:56425

Cold agglutinin disease is a type of autoimmune hemolytic anemia (see this term) defined by the presence of cold autoantibodies (autoantibodies which are active at temperatures below $\left.30^{\circ} \mathrm{C}\right)$. 